\title{
Antisemitism, critical theory and the ambivalences of Marxism
}

Citizens, let us think of the basic principle of the International: Solidarity. Only when we have established this life-giving principle on a sound basis among the numerous workers of all countries will we attain the great final goal which we have set ourselves. (Karl Marx - a speech given following a congress of the First International, 8 September, 1872) ${ }^{1}$

During my youth I rather leaned toward the prognosis that the Jews of different countries would be assimilated and that the Jewish question would thus disappear in a quasi-automatic fashion. The historical development of the last quarter of a century has not confirmed this perspective ... . The Jewish question, I repeat, is indissolubly bound up with the complete emancipation of humanity. (Interview with Leon Trotsky). ${ }^{2}$

Did universalism prepare the way for the antisemitism to come? Our answer may appear equivocal. We do not accept the judgment that the universalism of Enlightenment and the modern revolutionary tradition was simply a failure, but we do recognise that one function of universalism was to represent Jews as the embodiment of the particular and the enemy of humanity. Our conviction, though, is that a universalism that creates its own 'other' ends up as no universalism at all. This was not only, of course, a theoretical question. The reconstruction of the Jewish question had real consequences both for those designated as the other of the universal and for the wider democratic culture. The idea that the multiple problems of modernity could be solved by emptying the world of Jews was taken up with enthusiasm and urgency by antisemitic movements in the latter part of the nineteenth century; it turned out to have extraordinary mobilising power and to appeal to a wide range of political actors. If the legal recognition of Jews was being accomplished in most countries of Western Europe by the end of the 1870s, though not in the East, this was far less true of social recognition of Jews. The emancipation of Jews became an object of multiple resentments, which found political expression in the conceptualisation of the term 'antisemitism' 
itself as a self-identity and signifier of pride, and in the Europe-wide growth of antisemitic movements and parties.

'Antisemitism' was more than a new name for an old phenomenon; it was also the banner under which diverse hostilities toward Jewish emancipation could be mobilised; a reactive response to the equal treatment of a people not accepted as social equals. It gave a name to the belief that the harmfulness of Jews was made worse by their newfound invisibility and it stood for the restoration of a 'natural' hierarchy in society, in which the subordinate status of Jews would be restored through the enforcement of social and political distinctions. 'Antisemitism' presented the harmfulness of Jews no longer as a transitory and changeable characteristic but as the unalterable quality of their Jewishness. The continuing existence of the Jewish question post-emancipation appeared in the antisemitic imagination as evidence that the corruption of Jews was ineradicable and that the solution to the Jewish question required a harder edge than that of mere 'improvement' through processes of emancipation. Those who prided themselves as antisemites increasingly looked to the hard edges of internal exclusion, external expulsion or in extremis extermination.

The rise of antisemitism posed specific problems for emergent Marxist movements after Marx. Marxists generally rejected antisemitism, its essentialist contention that the harm caused by Jews was due to an unalterable Jewishness, and its repressive solutions to the problems it imagined; yet rejection of the 'immoderate' methods of posing and solving the problem did not mean repudiating their views on what is wrong or indeed 'repulsive' about them. Many Marxists were still tempted to explain antisemitism in terms of the harm Jews continued to inflict on society and to look to improvement in the behaviour of Jews as at least the first step in the struggle to do away with antisemitism. The description of antisemitism as the 'socialism of fools', usually attributed to the German Marxist August Bebel, was an evocative expression of Marxism's critical response to the rise of the phenomenon but was understood in some quarters as endorsing the view that antisemitism was a kind of socialism, albeit a foolish kind, and that it contained a kernel of truth that was a matter of concern for socialists as well as for antisemites. ${ }^{3}$ So while Marxists generally opposed antisemitism, they were also tempted to revive the assumptions of the Jewish question in their very way of understanding and responding to it. This is why Marxists could be as critical of 'philosemites' as of antisemites: while the latter made the problem worse by naturalising Jewish defects and declaring 'no more Jews', the former seemed to obscure the very real and corrosive social harms committed by Jews - especially, as Nietzsche put it, by the 'stock-exchange Jew' on the one hand and the 'ugliness of the recently immigrated Polish and Russian, Hungarian and Galician Jews ${ }^{34}$ on the other. This is also why the self-confidence of Marxism was that its own universalistic principles were incompatible with antisemitism and that the idea of a 'left antisemitism' was an impossible oxymoron, even as they 
re-affirmed the demand that the Jews must abandon their harmful habits and traits.

\section{Marxism and the Jewish question}

We have argued that Marx challenged the view that Jewish emancipation should be made dependent on the condition that Jews abandon their Judaism or on the hope that Jews surrender their identity as Jews as the quid pro quo of civic equality. At the same time Marx and Engels confirmed the cosmopolitan credo that the working class has no country: 'The nationality of the worker is neither French, nor English, nor German, it is labour, free slavery, self-huckstering. His government is neither French, nor English, nor German, it is capital'. seemed to have an optimistic assessment of the empirical state of working-class consciousness when they wrote that 'the great mass of the proletarians are, by their nature, free from national prejudice and their whole disposition and movement is essentially humanitarian, anti-nationalist' ${ }^{6}$ but the normative conception of human community on which this assessment was based was to look for solidarities beyond the division of the world into separate nations. ${ }^{7}$ They doubtless mistook the wish for the deed when they argued that 'national differences and antagonisms between people are daily more and more vanishing' and that 'national one-sidedness and narrow-mindedness become more and more impossible', ${ }^{8}$ but their normative concern was to encourage class solidarity both within and across national boundaries - a solidarity imperilled by the appeal of rival nationalisms. In the revolutions of 1848 , for example, they were critical of German revolutionaries who resisted the application of the right of national self-determination they claimed for themselves being applied to Danes, Poles, Italians and Czechs, and they led the internationalist section of the left in opposing any such divisive expressions of German nationalism. ${ }^{9}$ They recognised the existence of national distinctions but refused to give them privileged status and challenged the dichotomy between 'universal' and 'non-historic' nations ('us' and 'them'). ${ }^{10}$

After Marx, however, orthodox Marxism took a nationalist turn, which was fateful in terms of its understanding of the Jewish question. In a context in which Jewish minorities were becoming increasingly vulnerable as the result of the growth of antisemitism and decline of the nation state, international solidarity with Jews became ever more vital. The situation was described thus by the writer, Joseph Roth:

Every nationality within Austria-Hungary pressed its claim on the basis of its 'territory'. Only the Jews ... had no territory of their own. In Galicia the majority of them were neither Poles nor Ruthenians. However, anti-Semitism was to be found equally among Germans and Czechs, Poles and Ruthenians, Magyars and 
Romanians in Transylvania. They managed to refute the proverb that says that when two quarrel, the third is always the winner. The Jews were always the third party and they always lost. ${ }^{11}$

The devaluing of cosmopolitanism and revaluing of the Jewish question combined to disfigure Marxist opposition to antisemitism and in some cases to make its own contribution to the antisemitic canon. The critical stance adopted by Marx and Engels was not entirely abandoned, but repeated attempts were made to replace the critique of nationalism with distinctions between progressive and reactionary forms of nationalism. ${ }^{12}$ The most influential of these distinctions was the opposition, endorsed by Lenin, between the 'nationalism of the oppressor' and the 'nationalism of the oppressed'. Lenin's own argument was partly instrumental, advanced in the hope that Marxists might be able to join forces with national resistance to Tsarist imperial rule, and partly empirical, based on the imperial division of the world between colonisers and colonised. The reification of this situated theory into a general doctrine, however, fell to Joseph Stalin who contrived a set of 'mathematical formulae' to determine who constituted a nation and what kind of nation they constituted. ${ }^{13}$ One of the effects of this move was to facilitate the old refrain that the Jews were not a nation and could not form one. This paradigm was to find its exemplar in the portrayal of Russia as the universal nation whose own interests corresponded with the general interests of world proletariat and the corresponding portrayal of the Jews as a mere semblance of a nation, in reality 'rootless cosmopolitans'.

Of course, not all Marxists at all times were prepared to abandon Marx's cosmopolitan outlook. Rosa Luxemburg, for example, is well known for stressing the dangers of nationalism: that it created barriers between workers, since it promoted the primacy of national identities and made loyalty to the nation a supreme political value. She maintained that it turned the right of nations to self-determination into a warrant for new states to oppress minorities in their midst - a warrant that was to have serious consequences for Jews, who were minorities in both old and new states. ${ }^{14}$ Whereas the Marxist mainstream formally offered uncritical support for a general 'right of nations to self-determination', Luxemburg tempered this doctrine by arguing that while self-determination is a democratic right and essential to struggles against imperial domination, it was being perverted as a thoroughly undemocratic justification for nationalist elites to try to construct homogenous populations with a uniform sense of identity. In the aftermath of the First World War, which Luxemburg had opposed from a broadly cosmopolitan perspective, the newly formed nation states of Central and Eastern Europe manifested just such a drive to homogenise populations and do what was necessary to achieve it, including the exclusion of minorities deemed to belong to other nations or, as in the case of the Jews, to no nation at all. ${ }^{15}$ In this context Luxemburg re-affirmed the significance of Marx's critique of the 
Jewish question at a time when leading Marxists of the German Social Democratic Party effectively came to adopt Bruno Bauer's uncritical absorption by the Jewish question. ${ }^{16}$ She demonstrated a better understanding of the dangers antisemitism posed than did orthodox Marxism. Not untypically for Marxists, she was slow to respond to antisemitism at the time of the Dreyfus case; here the initiative was taken more readily by 'reformists' such as Jean Jaures, ${ }^{17}$ but by the time of the 1905 revolution she, not unlike Trotsky, recognised that antisemites, far from being winnable for the socialist cause, were its enemies. The failure of the Polish national movement to recognise the dangers posed by antisemitism confirmed Luxemburg in her view that the nationalism they prioritised aligned them effectively with the political Right. ${ }^{18}$

What happened in 1905 was a foretaste of more serious developments that Luxemburg experienced personally in the course of the German revolution of 1918-19. The forces mobilised on the Right to crush the revolution, notably in the Freikorps units from which Hitler first began to garner support and from whose ranks Luxemburg's own murderers sprang, had at the heart of their ideology a virulent antisemitism, providing what Geoff Eley has called a vocabulary of counter-revolutionary desperation'. ${ }^{19}$ The central object of their rage was the 'Judeo-Bolshevik' enemy that had supposedly caused Germany's defeat and had now to be exterminated. ${ }^{20}$ Nazism built on the ideological matrix within which the counter-revolutionary Right operated, and provided ways of organising otherwise fractured groupings. ${ }^{21}$ How did Marxist movements respond?

\section{Marxism and the final solution}

Mainstream Marxism, both in its reformist and revolutionary wings, was opposed to antisemitism and to the antisemitic parties, but did not understand the central role played by antisemitism for the counter-revolution. The temptation to think that there was a 'Jewish question' for society to 'solve' helps explain the reluctance of Marxists, whether Social Democrats or Communists, to make the struggle against antisemitism any kind of priority in spite of the fact that it was being radicalised and pushed to the fore by the Nazis. Inside Germany, neither wing of the Marxist movement appeared to think that antisemitism was central to the Nazi agenda. Both decided it did not call for specific rebuttal and rarely took direct action on this issue. ${ }^{22}$ The Social Democrats produced little propaganda to challenge the antisemitic arguments of the Nazis in the last years of the Weimar republic, and the party's attitude appears to have been shaped by fears that it would be over-identified with Jews. ${ }^{23}$ Once the Nazis came to power, the underground was instructed not to prioritise the issue on the grounds that antisemitism was more popular than originally estimated and that it would make the work of the resistance more difficult. Klaus Mann, though not himself a member of the Social Democratic Party, spoke for many on the non-Communist 
left when he too argued in 1941 that 'antisemitism has already played too predominant a part in our propaganda ... it is a dangerous mistake to overemphasise this one particular angle..$^{24}$ The German Communists had a still more problematic record in resisting antisemitism and flirted on several occasions with antisemitic discourse. In 1923 one of its leaders, Ruth Fischer, encouraged Nazi students 'to crush the Jewish capitalists, and hang them from the lamp posts', although she went on to urge them to hang other capitalists too. ${ }^{25}$ In the early 1930s, the Communist Party produced leaflets depicting Hitler in league with Jewish capitalists. ${ }^{26}$ In the Communist underground, no significant efforts were made to confront antisemitism and it was not until Kristallnacht that the party's paper Die Rote Fahne gave the issue any prominence. ${ }^{27}$ By the time of this state-sponsored violence, Jews had already been systematically removed from the German economy, polity and society.

As the Nazi assault moved beyond the borders of the German nation state to encompass Jews across Europe, and as the threat Jews faced from antisemitism was extended to their survival as members of the human species, Nazi antisemitism acquired what Saul Friedländer has called a 'redemptive' character. ${ }^{28}$ It articulated a picture of 'the Jews' as a profound danger, not to Germany alone but to Europe, the Aryan race and humanity. Only through the elimination of the Jews could the 'Jewish question' be 'solved' and humanity made whole again. Nazi antisemitism was a global project, nurtured inside one nation state and then broadened out to eliminate Jews from the world. German Marxists were not alone in failing to respond to the threat posed by Nazi antisemitism, but at a time when the legacy of Marx's critique of the Jewish question was most urgently needed, it was ignored, distorted or squandered. Resistance to the assault on Jews was circumscribed within a frame of reference that did not make what was happening to Jews a priority. For example, when Jews in France were being deported to the camps, the Communist Resistance was still reluctant to make antisemitism a major issue, and no propaganda was produced to highlight what was being done to the Jews in France or elsewhere. Recent research has corroborated that the Communist underground press effectively kept total silence ... even when an antisemitic propaganda campaign was launched and even when it directly targeted the resistance' and that 'throughout the occupation, the resistance spared no effort to prove that its members had not signed up to the goal of defending the Jews. ${ }^{29}$ There is compelling evidence that Jewish leadership of Communist resistance was seen as an embarrassment once the Communist parties adopted a super-patriotic line on instruction from Moscow in 1943, the year of the Comintern's official dissolution. The universalism which underpinned the commitment of Jews to the Communist resistance had been tested to the extreme at the time of the Nazi-Soviet pact and led to some Jews leaving the Party in disgust; now it was seen by the Stalinist leadership as such a potent source of disloyalty that they gave orders for Jewish Communist resistance groups 
in Paris and Toulouse to be betrayed to the Gestapo. ${ }^{30}$ None of this is to ignore 'the hand of compassion' offered to Jews by individuals and groups in extremely demanding conditions, ${ }^{31}$ but if there was a politics shared by these rescuers, it was informed less by Marxism than by a basic sense of cosmopolitan solidarity with Jews as fellow human beings.

The strategic responses of Marxists organised in Communist Parties were designed and directed from the Soviet Union, even if they were interpreted and applied at the local level. Here the refusal to face up to antisemitism, especially as it became genocidal, was to have disastrous consequences. One effect of the Nazi-Soviet pact of 1939, which allowed Hitler to fight a war of aggression against Poland with Soviet help, was that it was also effectively an arrangement with the most powerful antisemite in the world, which opened the way for the destruction of the largest homeland of Jews in the world. ${ }^{32}$ Stalin was well aware of Hitler's antisemitism, as indicated by his decision to fire his Jewish Commissar for Foreign Affairs, Maxim Litvinov, and replace him with the non-Jewish Russian Vyacheslav Molotov, in order to negotiate this agreement. By this time, many Jews had a developed sense of what was in stock for them. Five years of accelerating antisemitic repression in Germany had been followed by shocking violence against Jews in Austria after the Anschluss and in Czechoslovakia when it too was annexed. When news of the Molotov-Ribbentrop pact came through to the Zionist World Congress, everyone there understood what it meant for Jews. Chaim Weizmann, leader of the General Zionists, closed the congress with the words: 'Friends, I have only one wish: that we all remain alive'. ${ }^{33}$ The secret protocols of the German-Soviet agreement meant that the heartland of world Jewry in East Europe would quickly become the most dangerous place in the world for Jews. When Stalin said that the Molotov-Ribbentrop pact was an alliance 'signed in blood', he signally failed to note that much of the blood would be that of Jews. When large numbers of Jews fell rapidly under Nazi control in 1941, some managed to flee to the Soviet Union, but the Soviet state did not make any plans that took into account the dangers facing the Jewish population across the border. ${ }^{34}$ When the Nazis invaded the Soviet Union and the mass shootings of Jews began, the Soviet authorities maintained a systematic and sustained silence about what was happening. For example, the first report that 52,000 Jews had been murdered at Babi Yar was revised down to a figure of $1,000 .{ }^{35}$ The war itself was defined in national terms that had nothing to do with the murder of Jews as such. As one Military Council leader put it in 1943, citing Stalin, 'some comrades of Jewish descent believe that this war is being fought to save the Jewish nation. These Jews are mistaken. We fight the Great Patriotic War for the salvation, the freedom and the independence of our homeland led by the Great Russian people'. ${ }^{36}$ The practical consequence of this kind of national framing of the conflict with the Nazis was that Jews as Jews were left to fend for themselves. One historian maintains that 'neither from the Soviet state nor from 
the Party was there a single appeal to underground organisations or the local population to help Soviet Jews. ${ }^{37}$

After the Holocaust, such indifference evolved into a more familiar pattern. As the Red Army swept west, a Soviet Extraordinary State Commission to Investigate German-Fascist Crimes was set up and given specific instructions to avoid stating that the victims of massacres had been Jews. Along with four other anti-fascist committees, a Jewish anti-Fascist Committee (JAC) had been set up by the Soviet regime in 1942 and had made efforts to publicise for a Western audience what the Nazis were doing to Jews. One of its major projects, published in early 1946, was a detailed record of Nazi crimes, The Black Book: The Nazi Crime Against the Jewish People. The fate of this book and the committee is instructive. Even though the regime had carefully vetted membership of the JAC, it was, from the outset, concerned with potential deviations from party orthodoxy on the Jewish question. Drafts of The Black Book aroused serious concerns within the regime, precisely because of its emphasis on what was done to Jews, and it was withdrawn in late 1947 from publication on the grounds that it contained 'grave political errors'. All copies were destroyed, along with the typesetting. ${ }^{38}$ With the defeat of the Nazis, the JAC had outlived its tactical utility and it was closed down long before other anti-fascist committees. The first victim was its leading activist and spokesman, the playwright Solomon Mikhoels, who was murdered on Stalin's personal orders in January 1948. Other members, some of them die-hard Stalinists, were arrested, tortured, charged and in almost all cases shot. ${ }^{39}$ The two decisive charges laid against leaders of the JAC, those of Zionism and cosmopolitanism, appear at first sight bizarrely contradictory but what connected them were connotations of disloyalty, lack of patriotism, foreignness and investment in world Jewish conspiracy. The charge of 'Zionism' rested on a selective nationalism that claimed to distinguish between its 'progressive' and 'reactionary' forms and was premised on the disloyalty of Jews conspiring with other Jews to cling to a national identity they should have long foresworn. The phrase 'rootless cosmopolitan Jew' revealed an antipathy to cosmopolitanism, as well as to Jews, that Marx himself did not share. ${ }^{40}$ As one loyal Stalinist put it, 'cosmopolitanism is an ideology alien to the workers. Communism has nothing in common with cosmopolitanism, that ideology which is characteristic of representatives of banking firms and international suppliers of weapons and their agents'. Another described cosmopolitanism as 'a false, senseless, strange and incomprehensible phenomenon' and the cosmopolitan as 'a corrupt, unfeeling creature, totally unworthy of being called by the holy name of man'. ${ }^{41}$ The dual charges of Zionism and cosmopolitanism formed the basis of a distinctive contribution Stalinised Marxism made to the post-Holocaust repertoire of antisemitism, which was by no means confined to the Soviet Union. In the late 1940s and 1950s, this repertoire was polished in a series of show trials throughout Eastern Europe, most infamously in that of Rudolf Slansky in Eastern Europe, 
a template for many others. ${ }^{42}$ By combining apparent opposites, it re-connected with a long tradition in which Jews could be accused of seemingly contradictory crimes. What connected these charges as new forms of the Jewish question was the representation of Jews both as a transnational group with connections and loyalties which ran across national boundaries, and as a national group with connections and loyalties to a nation state of their own. Either way, Jews could be treated as enemies of the internationalism supposedly embodied in the Soviet state. ${ }^{43}$

Left Marxism, whose centre of gravity was the Trotskyist movement but which also included more libertarian sections of the radical left, was ferociously critical of Stalinised Marxism but was not necessarily able to frame a more coherent understanding of antisemitism. Although it is true that the official position of the Bolsheviks, at least after 1905, was that antisemitism was a fundamentally reactionary force, when it came to combating antisemitism even and perhaps especially during the revolution, the practice was quite different. As Brendon McGeevor has shown, the Red Army itself committed extensive antisemitic violence and was responsible for over $8 \%$ of pogroms launched in the Ukraine (Petluira's counter-revolutionary army being responsible for some 40\%). Prominent in the slogans pronounced by Red Army units as they fought their way across the Ukraine were calls to 'smash the bourgeoisie, smash the Yids. Long live Soviet power!' When efforts were belatedly made to contain this violence, they were organised not by the party leadership but by former members of the Bund and left-Zionist groups who had come over to the Bolsheviks at that time. ${ }^{44}$ They were all later murdered in the Stalinist terror of the 1930s. ${ }^{45}$

It is in this context that we might consider the evolution of Leon Trotsky's understanding of the threat posed by antisemitism. In 1905 Trotsky, like Luxemburg, had seen for himself how antisemitism had been whipped up by the state and how quickly it could mobilise and license the mob to perform acts of extreme violence. This did not prevent him being alarmingly slow, along with other Bolshevik leaders, to react to the antisemitic violence carried out by the Red Army, much of it before he assumed control, ${ }^{46}$ but he did have a more acute sense than other Marxists of where it might lead. Norman Geras has suggested that in Trotsky's evocative writing on the pogroms of 1905, we can find the roots of his foreboding in 1938 that with or without war 'the next development of world reaction signifies with certainty the physical extermination of the Jews' ${ }^{47}$ Trotsky's awareness of the genocidal thrust of Nazi antisemitism showed an ability to think critically about the Jewish question in ways that most of his followers were unable to comprehend or sustain. ${ }^{48}$

In the immediate aftermath of the Holocaust Ernest Mandel, who was to become one of the most influential of postwar Trotskyists, acknowledged the challenge posed by the Holocaust before equating the annihilation of the Jews to the postwar expulsion of Germans from Poland and Czechoslovakia: 'the death trains have again begun moving but this time in the opposite direction with a 
different human freight ... if Hitler constructed the trap for the Jews, it was the Anglo-Americans who sprang it ... the massacre of the Jews is borne equally with Nazism ... by all of imperialism. ${ }^{49}$ The analogy Mandel drew between the Holocaust and the expulsion of Germans, and that between Nazi culpability and imperialism more generally, signalled an unwillingness or inability to think about genocidal antisemitism as such. Mandel was by no means alone in displaying such reluctance. For example, those involved in one of the most intellectually fertile splits from orthodox Trotskyism, grouped around the journal Socialisme ou Barbarie, largely ignored the Holocaust. ${ }^{50}$ A similar neglect can be observed among the 1968 generation of radical leftists where various versions of Maoism jostled for influence with Trotskyists. ${ }^{51}$ The most influential Maoist group in France, Gauche Prolétarienne, represented itself as heir to the anti-fascist partisan movement and equated Israel's treatment of the Palestinians to Nazism - an early instance of what has subsequently become a common anti-Zionist thematic. While the Gauche Prolétarienne leaders eventually drew back from this position, recognising how easily it could slide into antisemitism, others were less reticent. ${ }^{52}$ Some sections of the German radical left also made this equation, leading to a shocking incident on the anniversary of Kristallnacht in 1969 when a bomb was planted in a Jewish community centre to draw attention to the ways in which the Jewish state had supposedly become the leading contemporary perpetrator of crimes against humanity or even genocide. ${ }^{53}$

Several decades after his first foray into writing about the Holocaust, Mandel reformulated his position. He now acknowledged that 'there can be no greater injustice than Auschwitz' and described its crimes as 'the worst in history', but he did not explore the centrality of antisemitism to the Nazi project. ${ }^{54} \mathrm{He}$ argued that the murder of other categories of 'sub-humans' was being planned by the Nazis, and that this was the result of a wider phenomenon - the emergence of a biological hyper-racism that legitimated imperialist exploitation. Mandel's reformulation was part of a growing literature exploring connections between imperialism and genocide, an approach that illuminates important elements of the Nazi project, especially in relation to the killing fields of Eastern Europe, ${ }^{55}$ but not the role of antisemitism in the conception and execution of the Holocaust. Jews were not just one of many targets but the primary focus of a movement designed to bring about their total annihilation; Jews were not just colonial subjects exploited in Eastern Europe but were transported there from all over Europe to be tormented, tortured and finally murdered. ${ }^{56}$

\section{Rethinking antisemitism: Adorno, Horkheimer and the Dialectic of Enlightenment}

While most Marxists had great difficulty in thinking about how Jews could be cast as such an enemy, we have seen that there were exceptions able to develop a more critical and self-critical approach. The most significant contribution to 
our understanding of antisemitism from within the Marxist tradition, widely conceived, was that developed by Max Horkheimer and Theodor Adorno. Their work on antisemitism may usefully be read as an engagement with and critique of the Marxist orthodoxy. Like the rest of their colleagues in the Frankfurt School, they were initially reluctant to make antisemitism a central focus of their research, and even as they deployed new methods of enquiry - designed to integrate insights from psychoanalysis into a Marxist frame of reference in order to explain how and why the proletariat failed to halt Hitler's rise to power - they eschewed any sustained discussion of antisemitism. Although many of the School's most prominent members were targeted as Jews, they initially preferred to downplay the question of antisemitism and think of themselves at risk predominantly because they were Marxists. ${ }^{57}$

It was not until 1938 that Horkheimer, the acknowledged director of the School, produced its first serious effort to think about antisemitism in his essay 'The Jews and Europe..$^{58}$ The emphasis on Europe in the title was promising in terms of breaking from a strictly national frame of reference but the essay was uneven, as Horkheimer himself later recognised when he decided not to have this essay republished in his collected works. Horkheimer reverted in this essay to an economistic form of Marxism that elsewhere he and his colleagues had gone beyond, seeking to explain what was happening to Jews primarily as an effect of changes in capitalism that made them economically redundant. Identifying Jews as representative of commercial capital, he argued that they were losing their social function as capitalism entered a new phase of development. 'The Jews are stripped of power as agents of circulation, because the modern structure of the economy largely puts that whole sphere out of action ... The result is bad for the Jews. They are being run over. Others are the most capable today: the leaders of the new economy and the state' ${ }^{59}$ Horkheimer's article has been criticised for the 'gloating and reproving tone' in which it appears to blame 'rich Jews' for antisemitism and for ignoring the substantial number of German Jews and huge numbers of Jews from further East who were not capitalists of any description, commercial or otherwise. ${ }^{60}$ Horkheimer's core assumption, however, was that the attack on Jews was a means to another end and a temporary product of 'the ascendant phase of fascism'.

At most, antisemitism in Germany is a safety valve for the younger members of the SA. It serves to intimidate the populace by showing that the system will stop at nothing. The pogroms are aimed politically more at the spectators than the Jews. ${ }^{61}$

This line of argument reappeared in the Frankfurt School's major work on the Nazi state, Franz Neumann's Behemoth (1942). Neumann insisted, at the very moment that the annihilation programme began in earnest with gas chambers 
fully operational, that the Nazis would 'never allow a complete extermination of the Jews. The foe cannot and must not disappear. ${ }^{62}$ Antisemitism was not an end in itself but 'only the means to the attainment of the ultimate objective, namely the destruction of free institutions, beliefs and groups ... the testing grounds for universal terrorist methods directed against all those groups and institutions not fully subservient to the Nazi system'. It was to be understood as 'a spearhead of terror'. Like other forms of Nazi ideology, which were 'mere arcana dominationis, techniques of domination', Neumann argued that antisemitism was used or discarded to fit the needs of the day. ${ }^{63}$ He wrote to Adorno that one could quite properly 'represent National Socialism without attributing to the Jewish problem a central role ${ }^{64}$ It might be argued that these members of the Frankfurt School, who were by then in American exile and far removed from where the killing was taking place, did not have sufficient information about what was happening to Jews. This is not, however, a compelling explanation, given that Neumann (as well as his close colleague, Herbert Marcuse) was employed as an analyst of Nazi Germany by the US government, which was better informed about the mass killing of Jews than was for many years admitted. ${ }^{65}$ It might also be argued that it is unfair to criticise members of the Frankfurt School with the benefit of hindsight given the widespread failure to understand what was happening to Jews. ${ }^{66}$ After all, 'even veteran anti-Semites found it hard to imagine that the Nazi regime seriously intended to make the Jewish people extincte. ${ }^{67}$ It is all the more remarkable, then, that Adorno and Horkheimer had the courage to re-think this approach to understanding antisemitism and the assumptions of the Jewish question running through it.

Adorno had already begun to have premonitions about what the Nazis might be intending. As one commentator has put it, Adorno 'seems to have become more sensitive to the approaching storm than others in the group' ${ }^{68}$ In February 1938, in a letter to Horkheimer, he raised the possibility of gassing and pointed to the acute vulnerability of Jews under existing national conditions: 'There can be scarcely any room for doubt that the remaining Jews in Germany will be wiped out; for as the dispossessed, no country in the world will grant them admission. ${ }^{69}$ What was being done to Jews was moving closer to the centre of their concerns. In August 1940 Adorno wrote to Horkheimer: 'under the influence of the latest news from Germany ... I cannot stop thinking about the Jews any more. It often seems to me that everything that we used to see from the point of view of the proletariat has been concentrated with frightful force upon the Jews ... who are now at the opposite pole to the concentration of power'. ${ }^{70}$ The antisemitism question was no longer a marginal issue. As Adorno put it, 'antisemitism is today really the central injustice, and our form of physiognomy must attend to the world where it shows its face at its most gruesome. ${ }^{71}$ This change of focus required radical rethinking. The elimination of a whole group of people, the attempt to remove them not only from one geographical area but 
also from the human world, raised fundamental questions about civilisation, the direction of historical development and the prospects for humanity itself. In 1942 Horkheimer wrote:

whoever accuses the Jews today aims straight at humanity itself. The Jews have become the martyrs of civilisation ... To protect the Jews has come to be a symbol of everything mankind stands for ... The Jews have been made what the Nazis always pretended they were - the focal point of world history. ${ }^{72}$

To understand how and why this group became the object of such dedicated destructive intent required a major re-assessment, not only of antisemitism but also of the Marxist tradition itself. Horkheimer came to realise, as he wrote to Marcuse, that 'the problem of antisemitism is much more complicated than I thought' and that to understand it, one had to connect economic and political factors with anthropological ones, to 'show these factors in their constant interconnection and describe how they permeate each other'. ${ }^{73}$

This major project was to be conducted at several levels. Horkheimer and Adorno began by sketching out a 'genealogy' of antisemitism. ${ }^{74}$ In a wide-ranging 1941 research proposal they suggested that this would require the study inter alia of the First Crusade, the Albigensian heresy, Jew-baiting in twelfth- and thirteenth-century England, the Reformation, the French Revolution, the German war of resistance to Napoleon, and political antisemitism in the nineteenth and twentieth centuries! ${ }^{75}$ This comprehensive historical study was to be accompanied by a series of research projects into contemporary antisemitism, including in the United States where they had been based since leaving Germany. Working with Jewish organisations such as the American Jewish Committee and the Jewish Labour Committee, they developed several research proposals on antisemitism that involved collaboration with a wide range of scholars. ${ }^{76}$ At the same time, Horkheimer and Adorno fundamentally recast their approach to antisemitism as part of a larger re-appraisal of the Enlightenment legacy in their Dialectic of Enlightenment, the last chapter of which was devoted to analysing 'the elements of antisemitism' and 'the limits of Enlightenment' antisemitism represented. ${ }^{77}$ This was the culmination of an argument they were working out in the book, to explore how it was that the development of civilisation regressed into the endeavour of a modern state (in one of the most advanced societies in the world) to murder a whole category of people and erase the idea of humanity.

One source of inspiration for this project was located within the Marxist tradition. At the outset of the First World War, when Rosa Luxemburg was resisting the nationalism to which many of her peers on both sides of the conflict had succumbed, she recalled Engels' warning that modern civilisation might regress into barbarism. In contemplating such a possibility, Luxemburg sketched out 
what barbarism might mean: 'the destruction of all culture ... depopulation, desolation, degeneration, a vast cemetery'. ${ }^{78}$ The example she drew on was that of the genocide of Armenians, committed by one of the warring parties during the First World War, the Ottoman regime, with the connivance of the German state. ${ }^{79}$ This genocide provided not only a precedent but an inspiration to Nazis, as Hitler made explicit when he told his generals that 'no one now remembers the Armenians' (meaning, as Omer Bartov acidly comments, that he and his audience did remember all too well). ${ }^{80}$ The 'final solution to the Jewish question' arguably went beyond even what was done to the Armenians: the aim was not 'only' deportation, plunder and mass murder in one region under the cover of war, but to hunt Jews down across Europe and the world, including of course Palestine, and annihilate the whole lot. ${ }^{81}$

Why were Jews singled out for extermination? The final chapter of Dialectic of Enlightenment did not come to a conclusion and was arguably not intended to do so. The title of the chapter 'Elements of antisemitism' suggested that no comprehensive explanation was possible or desirable. The concern of Horkheimer and Adorno was not to provide the kind of determinist account one finds in orthodox Marxism, which would mean that what happened had to happen, but to keep history open, i.e. to resist closure and avoid final conclusions. It was not necessarily a weakness that there was no clear hierarchy among the 'elements' they discussed. ${ }^{82}$ Their approach was rather an attempt to understand how the different elements of antisemitism were combined and recombined, and why the appearance of one element did not necessarily entail the disappearance of another. ${ }^{83}$ As the use of the term 'dialectic' in the book title suggests, older elements could be preserved and subsumed within the new framework. This is what Horkheimer and Adorno argued, for example, in the case of religious forms of antisemitism, which were variously 'channelled' or 'converted' into secular forms. ${ }^{84}$ At various points, Horkheimer and Adorno appear to regress to earlier positions mainstreamed within Marxism: sometimes to economic reductionism, sometimes to holding Jews responsible for their own predicament, sometimes to the suggestion that Jews might be interchangeable with any other group. No thinkers easily break free from initial assumptions, and the difficulties of understanding posed by what was happening to Jews were so acute that it was tempting to resort to familiar nostrums. What is striking about this work is how much rethinking of their original presuppositions was nonetheless involved and how this process of rethinking appears, as it were, on the page itself.

Adorno and Horkheimer began with a statement of recognition of the gravity of the problem. The acute danger facing Jews is that they have been 'branded as absolute evil by those who are absolutely evil ... marked out as the absolute object of domination pure and simple ... who must be wiped from the face of the earth'. ${ }^{85}$ Although they briefly reverted to Horkheimer's original argument 
that workers were the 'ultimate target', they took up the core issue raised in Marx's critique of Bauer, the connection between Enlightenment and the Jewish question, now reformulated in terms of the connection between liberalism and antisemitism. They maintained that liberalism appeared fundamentally opposed to Nazi antisemitism but could not provide the basis for a coherent response as long as it continued to assume that Jews had to give up something of their Judaism as the condition of becoming part of civilised society. To be sure, Horkheimer and Adorno recognised that not all liberals pathologise Jewishness, any more than all Enlightenment thinkers singled out Judaism as uniquely toxic, but they argued that assimilationist tendencies in liberalism were based on the assumption that the society into which Jews were supposed to assimilate possessed a unity and harmony that could only be disrupted by the persistence of a distinct and harmful Jewish identity. The apprehension they expressed is that the homogenising sense of national identity into which liberalism was drawn was moving inexorably in racist and antisemitic directions. Lurking within the liberal tradition, Horkheimer and Adorno discerned a potential for prejudice and persecution which found expression in the exclusion of Jews from the national community: 'The harmony of society which the liberal Jews believed in turned against them in the form of the harmony of a national community' ${ }^{86}$ The mistake was to think that 'antisemitism would distort that order which in reality cannot exist without distorting men. The persecution of the Jews, like any other form of persecution, is inseparable from that system of order ${ }^{97}$

To be sure, Horkheimer and Adorno were tempted to explain antisemitism, as Horkheimer had done in 1938, as a 'diversion' by the 'ruling clique' that appealed to 'covetous mobs', but they understood that this scapegoat approach cannot explain why Jews were targeted ${ }^{88}$ What was needed was the recognition of antisemitism as 'deep-rooted in civilisation ... a deeply imprinted schema, a ritual of civilisation' itself'. ${ }^{89}$ They returned to the economic argument that insofar as Jews were confined to commercial and financial forms of capital, it was because they were 'still largely denied access to the origins of surplus value', but called for an understanding of how and why Jews are made into 'scapegoats not only for individual manoeuvres and machinations but in a broader sense, inasmuch as the injustice of the whole class is attributed to them'. Involved here was what Horkheimer and Adorno called the 'concealment of domination in production ... an ideology cloaking the real nature of the labour contract'.$^{90}$ If what is concealed is represented as the fault of the Jews, antisemitism must play a key role in the legitimation of capitalism. At times Horkheimer and Adorno inverted the whole imagery of Jewish particularism characteristic of the Jewish question, declaring for instance that Jews have always been 'colonisers for progress': 'From the time when, in their capacity as merchants they helped to spread Roman civilisation throughout Gentile Europe, they were the representatives - in harmony 
with their patriarchal religion - of municipal, bourgeois and finally industrial conditions'. This was more than an economic role. Jews helped develop core ethical principles of the modern world only to discover that these principles did not apply to them: "Those who proclaimed individualism, abstract justice and the notion of the person are now degraded to the condition of a species ... they are never allowed to enjoy freely the civil rights which should allow them human dignity'. ${ }^{11}$ The idea that Jews need to be civilised is turned on its head. That civilisation can turn on Jews in the name of progress can only mean there is something wrong with 'civilisation' and 'progress'.

Part of this interrogation involved rethinking the relationship of antisemitism to Christianity. Horkheimer and Adorno saw it as a mistake to think that the religious hostility that lay behind two thousand years of persecution of Jews had simply disappeared. Religion had been 'subsumed and not abolished' and a distinctively religious antisemitism remained available as a resource, even if secular antisemitism claimed to ignore religious considerations. That some did not ignore them was evident within the German Church in which, as they tartly observed, antisemitism was 'all that the German Christians have retained from the religion of love..$^{92}$ The Enlightenment orthodoxy generally reserved greater scorn for Judaism than for Christianity: it saw Christianity as more universalistic than Judaism, since the Christian word of God was for all humanity while Judaism was for the chosen people alone, and as more imbued with the spirit of self-reflection, since it did not just follow the letter of the law: 'Do not be afraid; the Law is secondary to faith'. ${ }^{93}$ Horkheimer and Adorno responded that in one respect Christianity represented a 'regression behind Judaism': beneath its apparently more enlightened version of monotheism there was a return to a primitive view of the world, which re-imported the pagan 'man-God' based on the assumption that 'the man Jesus has become God'. The temptation Adorno and Horkheimer found within Christian universalism was to represent the continued existence of Judaism as an obstacle to human progress - a stubborn problem that would not go away. They traced 'the religious origin of antisemitism' back to the notion that 'the adherents of the religion of the Father are hated by those who support the religion of the Son - hated as those who know better. ${ }^{9}{ }^{4}$

Horkheimer and Adorno picked up on the wing of Enlightenment and then of socialism that sought to make a decisive break from the Jewish question. Antisemitism has to do with what is projected onto Jews, not with the conduct of Jews themselves. What was needed was an understanding of 'the mental energy harnessed by antisemitism, ${ }^{95}$ which they identified with projection of what is intolerable inside oneself onto Jews: 'Antisemitism is self-hatred, the bad conscience of the parasite..$^{96}$ This is why Horkheimer and Adorno distinguished between projection as such, which is necessary to all perception based on the 'distinction between within and without' and on the possibility of 'self-awareness 
and the conscience, ${ }^{97}$ and false projection characterised by absence of reflection:

since he [the antisemite] no longer reflects on the object, he ceases to reflect upon himself ... Instead of the voice of conscience, he hears other voices; instead of examining himself in order to decipher the protocol of its own lust for power, [he] attributes the 'Protocols of the Elders of Zion' to others ... It [false projection] invests the world boundlessly with its own content. ${ }^{98}$

The content of antisemitism is filled with 'fantasies of Jewish crimes, infanticide and sadistic excess, poisoning of the nation and international conspiracy'. While these fantasies go back a long way, what was new to the Nazi period was their 'practical implementation' which 'goes beyond the evil content of the projection'. ${ }^{99}$ Nazism was a 'special case of paranoiac delusion' ${ }^{100}$ Common to all paranoiacs is confusion between the inner and the outer world: 'Impulses which the subject will not admit as his own even though they are most assuredly so, are attributed to the object - the prospective victim'. In genocidal antisemitism 'this behaviour is made political: the object of the illness is deemed true to reality; and the mad system becomes the reasonable norm in the world'. ${ }^{101}$ While the 'solitary paranoiac' interprets the world 'in a private manner which is shared by no one and therefore appears totally mad', among Nazis 'illness is socialised ... Projecting their madness, they see conspiracy ... everywhere. ${ }^{102}$ Their project is to eliminate opposition through violence, first against individuals and then against collectivities through a 'carefully conceived strategy of extermination'. ${ }^{103}$ Violence binds the community as a racialised nation: 'the normal member of society dispels his own paranoia by participation in the collective form and clings passionately to the objectivised, collective and confirmed forms of delusion'. ${ }^{104}$ The corollary of Nazi paranoia is the desire for omnipotence: 'The antisemites try to realise their negative absolute by their own power, and change the world into the hell which they always thought it was. ${ }^{105}$ The elimination of difference becomes a 'substitute for omnipotence. It is as though the serpent who said to the first men "you will be as God" had redeemed its promise in the paranoiac. He makes everything in his own image. ... His will permeates the universe'. The desire for total domination is 'the mocking image of divine power ... like the devil ... driven by compulsion ... If it is said that divine power attracts creation, satanic power likewise draws everything into its own impotence. This is the secret of its domination'. 106 'The Jews' of antisemitic paranoia are thought to

lag behind civilisation and yet to be too far ahead of it: they are both clever and stupid, similar and dissimilar. They are declared guilty of something which they ... were the first to overcome: the lure of base instincts, reversion to animality ... the service of images. Because they invented the concept of kosher meat, they are 
persecuted as swine. The antisemites make themselves the executors of the Old Testament: they want the Jews who have eaten of the tree of knowledge to return unto dust. ${ }^{107}$

The return of the Jews, who were in fact 'defenceless victims', unto dust found its juridical protection 'in the name of the legal principle of sovereign national rights, which tolerates any act of violence in another country' ${ }^{108}$ There appeared to be nothing to stop the Nazis going ahead with their paranoid projection: to 'forcibly make over [the Jews] into a physical semblance of that image of death and destruction', which they with their 'fantasies of Jewish crimes' projected onto them. ${ }^{109}$

\section{Contributions of critical theory to the critique of the Jewish question}

Adorno and Horkheimer's analysis of the elements of antisemitism reveals that it was, as Horkheimer already sensed, a more complicated question than they previously thought. To think about it, they had to break radically from the assumptions of the Jewish question in all its variants, including those of orthodox Marxism, and reconstruct its critique in the context of its 'final solution'. The further question that arose for Horkheimer and Adorno was what would happen to antisemitism after the Holocaust, once there was general recognition of the barbarism it represented. Would such recognition designate the disappearance of antisemitism? They feared this might not be the case. Although Nazi Germany was militarily defeated and the Holocaust was stopped before the 'final solution' was fully final, there could be no guarantee that antisemitism would simply disappear from the social and political landscape. The dissection of different elements of antisemitism in Dialectic of Enlightenment suggests that it was possible for them to be added to and recombined in new ways as long as there was a Jewish question to consider. In defeated Germany, they found evidence of a persisting Jewish question being rearticulated in new ways. In a study conducted in 1950-1951, when they had returned to Germany, they maintained that in some quarters antisemitism had been reworked and protected behind a wall of sophisticated defence mechanisms, which turned the perpetrator into victim and victim into perpetrator. ${ }^{110}$ They saw this inversion as a distinctive feature of post-Holocaust antisemitism. The defensive move to accuse the Jews of their own crimes revealed a reluctance to think about what was done to Jews or about the return of antisemitism. Adorno deployed the term 'secondary antisemitism' to conceptualise a prejudice he found extant among some Germans, that 'the Jews' were culpable of exploiting German guilt over the Holocaust. He argued that the existence of secondary antisemitism in postwar Germany expressed a failure to see the difference between merely mastering the Nazi past (Vergangenheitsbewaltingung) and 
working through it (Aufarbeitung der Vergangenheit); between a superficial break with Nazi rule and the greater challenge of reflecting on the roots of antisemitism in the modern age.

On the radical left, there was much justified criticism of the continuing presence of former Nazis in German society and the German state and of the reluctance of older generations to examine what had been done to Jews. Consumed by the idea that fascism had not been definitively vanquished, however, a way of thinking developed within the left that came to the reductive judgment that there was in the end no significant difference between liberal democracy and Nazism. In the 1960s, in the course of rightful protests against the Vietnam War, this critique was extended to the United States and the West more generally. The place of Israel in this frame of reference was particularly striking. The Jewish nation came to be seen as the archetypal perpetrator of imperialist crimes accused of committing the same crimes against the Palestinians as the Nazis had committed against the Jews. The Jews became the new Nazis. Fortunately, this was not the only response within the Marxist left but it set the scene of a reconfiguring of the Jewish question. It was in part because Adorno and Horkheimer had come to reject this frame of reference that they were forced to part ways with a student movement that they had inspired. ${ }^{111}$

Adorno and Horkheimer understood that antisemitism is not invariant but an evolving social phenomenon, that its various elements can be combined and recombined in different settings, that it is not the problem of one nation only but for humanity itself, and that it casts a very dark shadow on any claim that History is proceeding 'inevitably' or even 'dialectically' in a progressive direction. ${ }^{112}$ They revived an alternative tradition to face up to antisemitism not as a 'niche issue' or 'interlude' (zwischenspiel), as Adorno put it, but as a deeply rooted problem of humanity, and to see the 'final solution' as a catastrophe whose meaning was far from exhausted. ${ }^{113}$ They drew on a critique of the Jewish question that was formative for Marx but marginal to the mainstreams of Marxism.

The existence of a body of Enlightenment universalism that confronts the idea of a 'Jewish question' is too often glossed over. It was a great strength of critical theory both to re-affirm the validity of universalism as a principle, and to insist that it loses all meaning when set in opposition to the particular. Those approaches to Enlightenment that do not address its internal relation to antisemitism are as flawed as those that do not address its internal relation to slavery, for they both erase human suffering from the history of political thought. This is not to endorse a counter-current that knows how to condemn universalism for its exclusionary relation to Jews and slaves but remains oblivious to its humanist worth.

The question Horkheimer and Adorno posed in the shadow of catastrophe was whether the ruled can see and control themselves in the face of absolute 
madness and call a halt to it'. Their answer was conditional: 'If thought is liberated from domination and if violence is abolished, the long absent idea is liable to develop that Jews too are human beings. This development would represent the step out of an antisemitic society ... and into the human society ... The Jewish question would then be the turning point of history. ${ }^{114}$ We should hold firm to the idea that the Jewish question may have been such a turning point in the modern world, as we move to our next chapter on the Jewish writings of Hannah Arendt and the peculiar difficulties the Jewish question has posed for Jews themselves.

\section{Notes}

1 Karl Marx - a speech given following a congress of the First International, 8 September, 1872. Karl Marx, The First International and After, ed. David Fernbach (New York: Vintage), 325.

2 From an interview given by Leon Trotsky to correspondents of the Jewish press upon his arrival in Mexico. Republished in Fourth International Vol. VI, No. 12 (Whole No. 61), December 1945, https://www.marxists.org/archive/trotsky/1940/ $\mathrm{xx} /$ jewish.htm (accessed 2 October 2015).

3 This formulation is often attributed to August Bebel, the leader of the German Social Democratic Party for many years, although it has been suggested that the term originated not with him but with an Austrian liberal, Ferdinand Kronawetter. See Jack Jacobs, On Socialist and 'The Jewish Question' After Marx (New York: New York University Press, 1992), ch. 2 'Eduard Bernstein: After All. A German Jew'. It seems that Bebel was himself not entirely happy with the use of the term socialism in this context. In an interview conducted with Hermann Bahr in 1894, he expressed reservations about this formulation, noting that if some workers encountered Jews as small capitalists, most Jews were, especially in the East, workers or peasants, and most Germans knew nothing about Jews at all. Hermann Bahr, 'Der Antisemitismus - Ein Internationales Interview' in Claus Pias (ed.), Hermann Bahr: Kritische Schriften, vol. 3, 21-24, www.univie.ac.at/bahr/node/83302 (accessed 15 December 2015). We are grateful to Olaf Kistenmacher for alerting us to this caveat.

4 See Robert C. Holub, Nietzsche's Jewish Problem: Between Anti-Semitism and AntiJudaism (Princeton: Princeton University Press, 2016), 118-123.

5 Karl Marx and Friedrich Engels, 'Critique of List' in Collected Works, vol. 4 (London: Lawrence and Wishart, 1975 [1845]), 280. The significance for Marx's cosmopolitanism of this critique of List, as the leading contemporary exponent of nationalism in economic theory, is brought out well by Roman Szporluk in his Communism and Nationalism: Karl Marx versus Friedrich List (New York: Oxford University Press 1988). John Hall tellingly describes List as 'the Marx of nationalism' in The State of the Nation: Ernest Gellner and the Theory of Nationalism (Cambridge: Cambridge University Press), 31.

6 Friedrich Engels, 'The Festival of Nations in London' in Marx and Engels Collected Works, vol. 6 (London: Lawrence and Wishart, 1976 [1845]), 6. 
7 See Erica Benner, Really Existing Nationalisms: A Post-Communist View from Marx and Engels (Oxford: Oxford University Press 1995), 11.

8 Marx and Engels, 'The Communist Manifesto' in Marx and Engels Collected Works, vol. 6 (London: Lawrence and Wishart, 1976 [1848]), 483.

9 Dieter Langeswiehe, 'Germany and the National Question' in John Breuilly (ed.), The State of Germany: The National Idea in the Making, Unmaking and Remaking (London: Longman, 1992).

10 Michael Hughes, Nationalism and Society: Germany 1800-1945 (London: Edward Arnold, 1988). They were, of course, well aware that this was not only a 'German' temptation and, as Gilbert Achcar has noted, they were sharply critical of similar tendencies in France. Gilbert Achcar, Marxism (London: Saqi Books, 2013), 112. Engels took Louis Blanc to task, for example, for seeming to demand 'all others to become Frenchmen'. Friedrich Engels, 'The Reform Movement in France: The Banquet of Dijon' in Karl Marx and Friedrich Engels, Collected Works, vol. 6 (London: Lawrence and Wishart, 1976 [1847]), 399.

11 Joseph Roth, The Wandering Jews, trans. Michael Hoffman (New York: W.W. Norton and Co, 2001).

12 For a critical survey of various such attempts, albeit written from a perspective rather different to our own, see Ephraim Nimni, Marxism and Nationalism: Theoretical Origins of the Political Crisis (London: Pluto Press, 1991).

13 Enzo Traverso, The Marxists and the Jewish Question (New York: Humanities Press, 1994), 135.

14 For a collection of her oft-derided views on nationalism, see Rosa Luxemburg, The National Question, ed. Horace B. Davis (New York: Monthly Review Press, 1976). See also Anita Shelton, 'Rosa Luxemburg and the National Question', East European Quarterly, 21 (3), 1987: 297-303.

15 For various such efforts, see Rogers Brubaker, Nationalism and the National Question in the New Europe (Cambridge: Cambridge University Press, 1996). Hannah Arendt was particularly clear on the dangers such moves posed to Jews and other minorities in Origins.

16 On Luxemburg's retrieval of Marx's arguments, see Fischer, The Socialist Response to Antisemitism, 221-222.

17 In his defence of Dreyfus, Jean Jaurès too at times located his arguments within the prevailing Marxist framework, arguing that 'even for the benefit of a Jew, we have the right to demand legal guarantees' and even assuring one audience that he understood their antisemitism: 'Yes, down with the Jews! But down with the Christians who are Jews'. Cited in Ruth Harris, Dreyfus: Politics, Emotion, and the Scandal of the Century (New York: Metropolitan Books, 2010), 261. It was far from the case that those who defended Dreyfus were animated by their opposition to antisemitism; in fact, many committed Dreyfusards ended up collaborating enthusiastically with the Vichy regime. See Simone Epstein, Les Dreyfusards sous l'Occupation (Paris: Albin Michel, 2007).

18 For a careful discussion of a particularly instructive episode which attracted Luxemburg's attention at this time, see Fischer, The Socialist Response to Antisemitism, 218-220. 
19 Geoff Eley, 'What Are the Contexts for German Antisemitism? Some Thoughts on the Origins of Nazism, 1800-1945' in Jonathan Frankel (ed.), Studies in Contemporary Jewry, XII: The Fate of the European Jews, 1939-1945 (New York and Oxford: Oxford University Press, 1997), 125.

20 The need to exterminate the 'Jewish enemy', if another defeat was to be avoided, was a constant theme of Nazi propaganda which grew in intensity as the Second World War progressed. See Jeffrey Herf, Nazi Propaganda for the Arab World (New Haven, Conn.: Yale University Press, 2010). It found a willing audience in those who carried out the 'final solution'. Omer Bartov has demonstrated a clear connection between the antisemitic exterminatory fantasies of the Freikorps and those soldiers who were extensively involved in mass killing of Jews in the East. Both 'came to view their criminal actions ... as exacting a just and necessary retribution for past defeats and humiliations ... and thereby ensuring the final victory [over Judeo-Bolshevism]' and could 'portray mass killing of civilians [Jews] as a glorious and final reckoning with foes who had been poised to inflict untold barbarities on the German Volk'. Omer Bartov, Mirrors of Destruction: War, Genocide, and Modern Identity (New York: Oxford University Press, 2000), 28. Saul Friedländer (2007) has explained in his magisterial Nazi Germany and the Jews (New York: HarperCollins, 1997) that the Judeo element in the Judeo-Bolshevik couplet came first and had clear primacy.

21 Lee McGowan, 'The Extreme Right' in Panikos Panayi (ed.), Weimar and Nazi Germany: Continuities and Discontinuities (London: Longman, 2001), 246-272.

22 Donald Niewyk, Socialist, Anti-Semite and Jew: German Social Democracy Confronts the Problem of Anti-Semitism, 1918-1933 (Baton Rouge: Louisiana State, 1971).

23 David Bankier, 'German Social Democrats and the Jewish Question' in David Bankier (ed.), Probing the Depths of German Anti-Semitism: German Society and the Persecution of the Jews 1933-1941 (Oxford: Berghahn, 2000), 511-532.

24 Cited in Bankier, 'German Social Democrats', 521.

25 Cited in Davis William Daycock, The KPD and the NSDAP: A Study of the Relationship between Political Extremes in Weimar Germany, 1923-1933, PhD thesis (London School of Economics, 1980).

26 Timothy Brown, Weimar Radicals: Nazis and Communists Between Authenticity and Performance (New York: Berghahn, 2009), 104.

27 Jeffrey Herf, 'German Communism, the Discourse of "Anti-Fascist" Resistance and the Jewish Catastrophe' in Michael Geyer and John W. Boyer (eds.), Resistance in the Third Reich (Chicago: Chicago University Press, 1994), 257-294.

28 Saul Friedlander, Nazi Germany and the Jews 1939-45: The Years of Extermination (London: Weidenfeld and Nicolson, 2007), xviii.

29 Daniel Blatman and Renée Poznanski, 'Jews and their Social Environment: Perspectives from the Underground Press in Poland and France' in Beata Kosmala and Georgi Verbeeck (eds.), Facing the Catastrophe: Jews and non-Jews in Europe during World War Two (Oxford: Berg, 2011), 159-228, at 201.

30 On this shocking episode, see the careful investigation by Maurice Rajsfus, L'An Prochain la Révolution: Les Communistes Juifs Immigrés dans la Tourmente Stalinienne 1930-45 (Paris: Editions Mazarine, 1985), 197-226. 
31 Karen Monroe, The Hand of Compassion: Portraits of Moral Choice During the Holocaust (Princeton, NJ: Princeton University Press, 2004).

32 Timothy Snyder, Black Earth: The Holocaust as History and Warning (New York: Tim Duggan Books, 2015), 103.

33 Cited in Snyder, Black Earth, 103.

34 Ben-Cion Pinchuk, 'Was There a Soviet Policy for Evacuating the Jews? The Case of the Annexed Territories', Slavic Review, 39, 1, 1980, 44-55.

35 Arno Lustiger, Stalin and the Jews: The Red Book: The Tragedy of the Jewish Anti-Fascist Committee and the Soviet Jews (New York: Enigma, 2003), 106.

36 Lustiger, Stalin and the Jews, 108.

37 Quoted in Harvey Asher, 'The Soviet Union, the Holocaust and Auschwitz' in Michael David-Fox, Peter Holquist and Alexander M. Martin (eds.), The Holocaust in the East: Local Perpetrators and Soviet Responses (Pittsburg: University of Pittsburg Press, 2014), 29-50, at 44.

38 Zvi Gitelman, 'Politics and the Historiography of the Holocaust in the Soviet Union' in Zvi Gitelman (ed.), Bitter Legacy: Confronting the Holocaust in the USSR (Bloomington: Indian University Press, 1997), 19.

39 Joshua Rubenstein and Vladimir P. Naumov, Stalin's Secret Pogrom: The Postwar Inquisition of the Jewish Anti-Fascist Committee (New Haven: Yale University Press, 2001).

40 Gilbert Achcar argues persuasively that the antipathy to cosmopolitanism found within Marxist circles was not shared by Marx or Engels themselves, who were inclined to use the term positively rather than pejoratively. Achcar, Marxism, 123. Michael Löwy, similarly, claims that 'there is no doubt that Engels considered himself to be a consistent cosmopolitan'. Michael Löwy, Fatherland or Mother Earth? Essays on the National Question (London: Sterling, Va.: Pluto Press with the International Institute for Research and Education 1998), 8.

41 Quoted in Benjamin Pinkus and Jonathan Frankel. The Soviet Union and the Jews, 1948-67 (Cambridge: Cambridge University Press, 1984), 152 and 154.

42 Of the 14 defendants singled out in the Slansky trial, the largest of all the purge trials held in this period, at least 11 were Jews. See Tomas Snigeon, Vanished History: The Holocaust in Czech and Slovak Political Culture (Oxford: Berghahn, 2014), 61. Antisemitism had also been a feature of the Moscow trials of the late 1930s, where it formed a crucial 'subtext', and even before, in the context of actions taken against Trotsky in the 1920s. See Vadim Rogovin, 1937: Stalin's Year of Terror (Sheffield: Mehring, 1998), 154. On the antisemitic aspect of the campaign against Trotsky in the 1920s, see Bernard Wasserstein, On the Eve: The Jews of Europe Before the Second World War (New York: Simon and Schuster, 2012), 64.

43 See, for example, Orlando Figes, The Whisperers: Private Life in Stalin's Russia (London; New York: Allen Books, 2007), 454, and Frank Gruner, " Russia’s Battle Against the Foreign": The Anti-Cosmopolitanism Paradigm in Russian and Soviet Ideology' in Michael L. Miller and Scott Ury (eds.), Cosmopolitanism, Nationalism and the Jews of East Central Europe (London: Routledge), 109-136.

44 For a detailed study of this Red Army violence, see the PhD by Brendon McGeevor, A Historical Sociology of the Bolshevik Response to Antisemitism and Pogromist Violence During the Russian Revolution (Glasgow University, 2015). 
45 The murder of Jews as Jews was part (though not the central part) of Stalin's paranoia about some nationalities as sources of disloyalty to the Soviet Union at this time. On the murderous consequences of this paranoia for Jews as well as others (notably Poles), see Timothy Snyder, Bloodlands: Europe Between Hitler and Stalin (London: Bodley Head, 2010). This paranoia was not of course grounded in any cosmopolitan vision, nor was it at all incompatible with what was very soon to be an overt embrace of Russian patriotism in the 'Great Patriotic War' against Nazi Germany.

$46 \mathrm{McGeevor}$ argues that it was not possible for the party leadership to control much of what was going on at the base. Many of those who fought in the Red Army were peasant partisans who brought with them a long-standing and virulent antisemitism. Bolshevik commissars who tried to do something to contain the antisemitic violence (when they dared, which was rarely) were brushed aside.

47 Norman Geras, The Contract of Mutual Indifference; Political Philosophy After the Holocaust: (London: Verso, 1998), 158-159; the quotation (cited in Geras, 139) is from Trotsky, On the Jewish Question (New York: Pathfinder Press, 1970), 29. We are not aware of any other Marxist, or indeed any other prominent political or social theorist, who made such an acute diagnosis of what was looming at this time.

48 In a set of detailed interviews with Trotskyists in France, where the movement was most influential, Jean Birnbaum found an 'almost perfect identity of the revolutionary position ... before and after the bloody caesura', an insistence as a matter of principle on speaking as little as possible about antisemitism, and on rejecting anything which drew attention to the particular fate of Jews. Leur Jeunesse et la Notre: L'Espérance Révolutionnaire au Fil des Générations (Paris: Stock, 2005), 345. See, in particular, ch. 4 'Sois Juif et Tais-toi! L'Universalisme a Corps Perdu', 303-358.

49 Ernest Mandel, 'The Jewish Question since World War Two' republished in www.workersliberty.org/node/8914 [1946] (accessed 6 September 2014), 2; 3.

50 Concerning the dearth of Marxist scholarship on the Holocaust, see Philippe Reynaud, L'Extrême Gauche Plurielle (Paris: Editions Perrin, 2010) and Philippe Gottraux, Socialisme ou Barbarie: Un Engagement Politique et Intellectuel dans la France de l'Après-Guerre (Lausanne: Payot-Lausanne 1997). An exception is Arno Mayer's Why did the Heavens Not Darken? published by the radical publishing house Verso in 1988. This work, however, specifically sets out to downplay the role of antisemitism in the Holocaust.

51 Yair Auron, Les Juifs et l'Extrême Gauche en Mai 68: Une Génération Marquée par la Shoah (Paris: Albin Michel, 1998).

52 See Hervé Hamon and Patrick Rotman, Génération: Volume 2, Les Années de Poudre (Paris: Le Seuil 1988). For an interesting reflection by a member of the Gauche Prolétarienne on how and why antisemitism was systematically ignored, see JeanClaude Milner L'Arrogance du Présent: Regards sur une Décennie, 1965-1975 (Paris: Grasset, 2009) ch. 8, 'Le Juif de Révolution'. The leader of Gauche Prolétarienne, Benny Lévy, came to see an unwillingness on the left to think about antisemitism as a reason why it was prone to adopt unreflective pro-Palestinian positions. Lévy, who later turned to orthodox Judaism after a prolonged engagement with the work of Emmanuel Lévinas, was a major if contested influence on Jean-Paul Sartre, who shielded Lévy from Gaullist persecution. Lévy may have helped fortify Sartre's 
determined refusal to abandon his deep concern with antisemitism and his understanding of Israel as a refuge for Jews after the Holocaust. Many on the left were discomfited by this position of Sartre's and sought to blame Lévy, a charge rebutted convincingly by Sartre's adopted daughter Arlette Elkaïm-Sartre. Some of their discussions appear in Jean-Paul Sartre and Benny Lévy, Hope Now: The 1980 Interviews, trans. Adrian van den Houven (Chicago: University of Chicago Press, 1996). More generally on Sartre's refusal to collude with antisemitism, see Jonathan Judaken, Jean-Paul Sartre and The Jewish Question: Anti-Antisemitism and the Politics of the French Intellectual (Lincoln: University of Nebraska Press, 2006).

53 This alarming episode is discussed in some detail in Hans Kundnani, Utopia or Auschwitz: Germany's 1968 Generation and the Holocaust (New York: Columbia University Press, 2009), 88-91. On the reluctance of the radical left to address the antisemitism revealed by this incident, see the interview with Tilman Fichter, the brother of one of those who planted the bomb: 'The Antisemitism of the 68ers' in signandsight: Let's Talk European, 31 October 2005, www.signandsight.com/ features/434.html (accessed 4 December 2015).

54 Ernest Mandel (1999) 'Prémisses Matérielles, Sociales et Idéologiques du Génocide Nazi' in Gilbert Achcar (ed.), Le Marxisme d'Ernest Mandel (Paris: Presses Universitaires de France, 1999), 200-202.

55 On relations between imperialism and genocide, see amongst others the pioneering work of Dirk Moses, Empire, Colony, Genocide: Conquest, Occupation, and Subaltern Resistance in World History (Oxford: Berghahn, 2008); Donald Bloxham, The Final Solution: A Genocide (Oxford: Oxford University Press, 2009); and Dan Stone, Histories of the Holocaust (Oxford: Oxford University Press, 2010), especially ch. 5 on 'Genocide, the Holocaust and the History of Colonialism'. On Nazi empire-building in the East, see Wendy Lower, Nazi Empire-Building and the Holocaust (University of North Carolina Press: Chapel Hill, 2007); Mark Mazower, Hitler's Empire: How the Nazis Ruled Europe (New York: Penguin Press, 2008). For a more detailed discussion of these issues, see Philip Spencer, 'Imperialism, Anti-Imperialism and the Problem of Genocide, Past and Present', History, 98, October 2013: 606-622.

56 There were significant differences as well as similarities between the ways in which the Nazis conceived of the Jews and other victims of imperialist racism, a difference captured well by Enzo Traverso: 'In contrast to the imperialist view of the colonised, Nazism did not regard the Jews as a backward, savage, primitive people or one that was incapable of surviving the onward march of progress. It considered them not as an archaic element that had lingered on the path of civilisation but as civilisation's enemy'. Enzo Traverso, The Origins of Nazi Violence (New York: New Press, 2003), 74.

57 The downplaying of the Jewish aspect of oppression by Communist intellectuals is very well caught in a memoir of a daughter's relation to her Hungarian Jewish Communist father. See Yudit Kiss, The Summer My Father Died (London: Telegram Books, 2012).

58 Max Horkheimer, 'The Jews and Europe' in Stephen Eric Bronner and Douglas Kellner (eds.), Critical Theory and Society (London: Routledge, 1989 [1938]), 77-94. 
59 Horkheimer, 'The Jews and Europe', 89.

60 Rolf Wiggershaus, The Frankfurt School: Its History, Theories, and Political Significance (Cambridge: Polity Press, 1994), 364.

61 Horkheimer, 'The Jews and Europe', 92.

62 Franz Neumann, Behemoth: The Structure and Practice of National Socialism (London: Frank Cass, 1967), 125. Detlev Claussen argues that the 'inner circle' of the Frankfurt School did not accept Neumann's analysis when it was presented. Detlev Claussen, Grenzen der Aufklarung: zur Gesellschaflichen Geschichte der Modernen Antisemitismus (Frankfurt am Main: Fischer, 1987), 46.

63 Neumann, Behemoth, 125; 551; 221; 467.

64 Quoted in Anson Rabinbach, 'The Cunning of Unreason: Mimesis and the Construction of Antisemitism in Horkheimer and Adorno's Dialectic of Enlightenment' in In the Shadow of Catastrophe: German Intellectuals Between Apocalypse and Enlightenment, Berkeley: University of California Press, 2001), 184.

65 Some of the work of members of the Frankfurt School for the US government has now been published in Franz Neumann, Herbert Marcuse and Otto Kirchheimer, Secret Reports on Nazi Germany: The Frankfurt School Contribution to the War Effort, ed. Raffaelle Laudani (Princeton, N.J.: Princeton University Press 2013).

66 For a broader discussion of this question, see Jacob Katz, 'Was the Holocaust Predictable?' in Yehuda Bauer and Nathan Rotenstreich (eds.), The Holocaust as Historical Experience (New York: Holmes and Meier, 1981), 23-41.

67 Frank Chalk and Kurt Jonassen, The History and Sociology of Genocide (New Haven: Yale University Press, 1990), 324.

68 Detlev Claussen, Adorno: The Last Genius (Cambridge, MA.: Belknap Press of Harvard University Press, 2008), 235.

69 Claussen, Adorno, 235.

70 Max Horkheimer, Gesammelte Schriften vol. 16 Briefwechsel 1937-40, ed. Gunzelin Schmid Noerr (Frankfurt am Main: Fischer, 1995), 764.

71 Letter from Adorno to Horkheimer 2 October 1941, quoted in Wiggershaus, The Frankfurt School, 309.

72 Max Horkheimer, Gesammelte Schriften vol. 17 Briefwechsel 1941-48, ed. Gunzelin Schmid Noerr (Frankfurt am Main: Fischer, 1996), 599.

73 Horkheimer, Gesammelte Schriften vol. 17, 463-464.

74 James Schmidt, 'Genocide and the Limits of Enlightenment: Horkheimer and Adorno Revisited' in James Kaye and Bo Strath (eds.), Enlightenment and Genocide: Contradictions of Modernity (Brussels: Peter Lang, 2000), 81-102.

75 Max Horkheimer and Theodor W. Adorno, 'Research Project on Anti-Semitism', Studies in Philosophy and Social Science, 9 (1), 1941: 124-143.

76 See Eva Maria Ziege, Antisemitismus und Gesellschaftstheorie: Die Frankfurter Schule im Amerikanischen Exil (Berlin: Suhrkamp 2009); Thomas Wheatland, The Frankfurt School in Exile (Minneapolis; University of Minnesota Press, 2009).

77 Max Horkheimer and Theodor. W. Adorno, Dialectic of Enlightenment (London: Allen Lane, 1973 [1943]).

78 Rosa Luxemburg, 'The Junius Pamphlet: The Crisis in German Social Democracy' in Rosa Luxemburg Speaks ed. Mary-Alice Waters (New York: Pathfinder, 1970), 269. 
79 Taner Akcam, A Shameful Act: The Armenian Genocide and the Question of Turkish Responsibility (London: Constable 2007), xvi.

80 Omer Bartov, 'Extreme Violence and the Scholarly Community', International Social Science Journal, 54 (174), 2002: 509-518, at 510. On connections between the genocides of the Herero and Nama and that of the Jews, see Jürgen Zimmerer 'The Birth of the Ostland out of the Spirit of Colonialism: A Postcolonial Perspective on the Nazi Policy of Conquest and Extermination', Patterns of Prejudice 39 (2), 2005: 197-219; and Benjamin Madley, 'From Africa to Auschwitz: How German South West Africa Incubated Ideas and Methods Adopted and Developed by the Nazis in Eastern Europe', European History Quarterly, 35, 2005: 429-464. For a more sceptical view, which lays stress on developments inside Germany, see Robert Gerwarth and Stephan Malinowksi, 'Hannah Arendt's Ghosts: Reflections on the Disputable Path from Windhoek to Auschwitz', Central European History, 42, 2009: 279-300, and from an angle that emphasises the role of German military traditions, Isabel Hull Absolute Destruction: Military Culture and the Practices of War in Imperial Germany (Ithaca, N.Y.: Cornell University Press, 2005).

81 Klaus-Michael Mallmann and Martin Cüppers, Nazi Palestine: The Plans for the Extermination of the Jews of Palestine (New York: Enigma Books with United States Holocaust Museum, 2010).

82 See Martin Jay, 'The Jews and the Frankfurt School: Critical Theory's Analysis of Anti-Semitism' in Jack Zipes and Anson Rabinbach (eds.), Germans and Jews Since the Holocaust (New York: Holmes and Meier, 1986), 293.

83 Anson Rabinbach, 'Why Were the Jews Sacrificed? The Place of Antisemitism in Dialectic of Enlightenment', New German Critique 81, 2000: 49-64, at 61.

84 Horkheimer and Adorno, Dialectic of Enlightenment, 176.

85 Horkheimer and Adorno. Dialectic of Enlightenment, 168.

86 Horkheimer and Adorno, Dialectic of Enlightenment, 169.

87 Horkheimer and Adorno, Dialectic of Enlightenment, 170.

88 Horkheimer and Adorno, Dialectic of Enlightenment, 170.

89 Horkheimer and Adorno, Dialectic of Enlightenment, 170-171.

90 Horkheimer and Adorno, Dialectic of Enlightenment, 173, 174.

91 Horkheimer and Adorno, Dialectic of Enlightenment, 175.

92 Horkheimer and Adorno, Dialectic of Enlightenment, 176.

93 Horkheimer and Adorno, Dialectic of Enlightenment, 177.

94 Horkheimer and Adorno, Dialectic of Enlightenment, 179.

95 Horkheimer and Adorno, Dialectic of Enlightenment, 183.

96 Horkheimer and Adorno, Dialectic of Enlightenment, 176. David Nirenberg puts it well: 'what gave anti-Semitic ideas their power was not so much their relation to reality, but rather their exemption from reality checks - that is from the critical testing to which so many other concepts were subjected'. Nirenberg, Anti-Judaism, 466.

97 Horkheimer and Adorno, Dialectic of Enlightenment, 187.

98 Horkheimer and Adorno, Dialectic of Enlightenment, 189-190.

99 Horkheimer and Adorno, Dialectic of Enlightenment, 186. 
100 Horkheimer and Adorno, Dialectic of Enlightenment, 193.

101 Horkheimer and Adorno, Dialectic of Enlightenment, 187.

102 Horkheimer and Adorno, Dialectic of Enlightenment, 196-197.

103 Horkheimer and Adorno, Dialectic of Enlightenment, 191.

104 Horkheimer and Adorno, Dialectic of Enlightenment, 197.

105 Horkheimer and Adorno, Dialectic of Enlightenment, 199.

106 Horkheimer and Adorno, Dialectic of Enlightenment, 192.

107 Horkheimer and Adorno, Dialectic of Enlightenment, 186.

108 Horkheimer and Adorno, Dialectic of Enlightenment, 193.

109 Horkheimer and Adorno, Dialectic of Enlightenment, 186.

110 Theodor W. Adorno, Guilt and Defense: On the Legacies of National Socialism in Postwar Germany, ed. Jeffrey K. Olick and Andrew J. Perrin (Cambridge, MA: Harvard University Press 2010).

111 Claussen argues that antisemitism was the key issue that led Adorno and Horkheimer to break with the student movement. Claussen, Grenzen der Aufklarung, 14.

112 Walter Benjamin has famously insisted that history needs to be considered from the vantage point of those whose lives are wrecked, even to the point of almost complete destruction. Benjamin, 'Theses on the Philosophy of History'. On the connection between Benjamin's general perspective here and Horkheimer and Adorno's specific approach to the Holocaust (much of which Benjamin did not live to see since he died trying to flee the Nazis in 1940 before the extermination project began in earnest), see Orietta Ombrosi, The Twilight of Reason: W. Benjamin, T.W. Adorno, M. Horkheimer and E. Levinas, tested by the Catastrophe (Boston, MA: Academic Studies Press, 2012).

113 On the need for and impediment to reflection and self-reflection, see Claussen, Grenzen der Aufklarung, 14 ff.

114 Horkheimer and Adorno, Dialectic of Enlightenment, 199-200. 